\title{
Role of Microcredit on the Education: A Study on NGOs in Bangladesh
}

\author{
Ishita Roy $^{1^{*}}$, Pronab Biswas ${ }^{2}$ \\ ${ }^{1}$ Assistant Professor, Department of Management Studies, Bangabandhu Sheikh Mujibur Rahman Science and Technology University, \\ Gopalgonj 8100, BANGLADESH \\ ${ }^{2}$ Department of Management Studies, Bangabandhu Sheikh Mujibur Rahman Science and Technology University, Gopalgonj 8100, BANGLADESH \\ *E-mail for correspondence: ishita ipu@yahoo.com
}

\begin{abstract}
Bangladesh is a pioneer of the conceptualizing micro-credit program. It has undertaken some such programs to reduce poverty and bring about socio-economic changes in the rural community. Among them, microcredit plays vital role in promoting education. So micro-credit is considered as vital tools to promote the education and reduce drop out. Presently Microfinance popularly known as microcredit. Now there are many types of microcredit organizations, we can see throughout the country. The common micro-credit institutions are GB, BRAC, ASA. This study explores the role of micro credits on the education, who had acquired micro credits from different microcredit organizations. Primary research was carried out with the help of a major NGO's who give loan for education. Two hundred in-depth personal interviews were conducted by the author Roy, I. and Biswas, P. from February to August 2015. Most of the developing countries like Bangladesh; people are poor especially in the rural areas people who are unable to send their children to school. Though Bangladesh Government provides some reading and writing materials to all level of students throughout the Bangladeshi students. But it is not sufficient, and it can't motivate parents to send their children school. Because of the high cost of education parents are discouraged to educate their children. In such a situation some major microcredit institutions provide money for their children education who is the member of these institutions. They sometimes provide money without any condition or sometimes conditionally. Such major micro-credit organizations are GB, BRAC, and ASA.
\end{abstract}

Keywords: Grameen Bank, BRAC, ASA, Micro-Credit, Education, Frequency, Zero-order correlation

\section{INTRODUCTION}

Micro credits, or more generally speaking microfinance, can be defined as offering small loans to facilitate the productive economic activity (Gibb, S. 2008). Since the late 1970s, microcredit has been popular in the developing world (Feng, C.C. 2013). It is estimated that nearly 80 percent of the villages in Bangladesh are now covered under NGO's activities but not necessarily 80 percent of the poor who need help. (Kabir, M.Dey, A, S. \& Islam, M.S. 2012). Now there are hundreds of association for microcredit providers of different operational sized throughout the country, mostly in rural areas but also some in urban areas. (Kumar, D. Hossain, A \& Chandra M. G. 2013). Now, Bangladesh boasts a large number of well-known microfinance institutions (MFIs) including Grameen Bank, BRAC, and ASA. (Yuge, Y. 2011). Bangladesh is a developing country having a very limited financial market. The deprived people do not get access to formal financial institutions because of lack of physical collateral (Ahshanullah, M. Karim, R \& Haq, E. 2011). As of June
2008, there were approximately 24 million active microfinance borrowers and 28 million members in Bangladesh (Yuge, Y. 2011) Education is regarded as a primary driver of economic growth as well as an effective way out of poverty (Hytopoulos, E. 2011). It also creates more choices, opportunities, and empowerment for individuals (Feng, C.C. 2013). This study finds that children tend to stay longer in schools when their family receives loans from microcredit organizations. Similarly found in Bangladesh that microcredit programs increase schooling and the contraceptive behavior of families (Becchetti, L. \& Conzo, P. 2010). Similarly looking at the potential impact of microfinance on parents' attitudes towards education, found that, although microcredit clients noticed the importance of education and were willing to invest more in their children, they were not more involved in their children's education and did not know more about their children's studies compared with the parents who were not microcredit clients (Hytopoulos, E. 2011). 


\section{IMPACT OF MICROCREDIT ON EDUCATION}

Bangladesh is a developing country. So, numerous scholars and various types of NGOs have been working to take micro-credit within the reach of poor people, who aren't still usually benefited by the conventional financial system (Kabir, M.A, Dey, S, and Islam, M.S. 2012). Nowadays, a broad-based consensus has emerged that children's education, and in particular the education of girls, is one of the crucial ingredients for a country's economic growth and its sustained human and economic development (Holvoet, N. 2004). Comparing the effects of slightly diverging credit programs that are operational in South India leads to the conclusion that in the case of direct bank-borrower credit it does not matter for children's education whether credit is in the hands of mothers or fathers (Holvoet, N. 2004). Microfinance has impacts on many aspects of society. Education and health are among the areas in which microfinance is expected to have positive impact (Feng, C.C. 2013). When microcredit provides a consistent income to sustain a family by providing for necessities and survival, these borrowers are then able to direct time and attention to achieving social goals in her community. Many are given the ability to choose to send their daughters to school and are now doing so because they recognize the importance of education in helping to break this vicious cycle of poverty. Provision of education for the next generation acts as a possible indicator for assessing the social impact of microcredit (NAI, E. 2010). If interest rates are kept low, payments are collected in a reasonable amount of time, and support in regarding education and advice are granted to borrowers, microcredit can continue to impact positively and empower women in Bangladesh and abroad (Loro, L. 2013).

\section{THE ACTIVITY OF MICROCREDIT ORganizations}

\section{ASA}

PESP of ASA provides measures to help those kids by operating learning centers in the backward areas of the country. Under the program, 7,266 Learning Centers have been set up in the underdeveloped localities especially in rural areas across the country. For each Learning Centre, a Sikha-Sebika (mentor) is assigned who provides learning support to 25-30 students through holding a two-hour class/session every day over six days in a week. Students are aided to organize their daily lessons and homework assigned by the school teachers. Also, in the learning centers students get involved in extracurricular activities like, singing, dancing, recitation, comics, acting, etc. once in the week that help to build their level of confidence (Annual Report, 2014-15.)

A meeting is held every month at each Learning Centre with the participation of guardians, mentor, and supervisor. It is necessary to mention that a supervisor has also been assigned to monitor the activities of 15 Learning Centers of PESP (Annul Report, 2014-15).

\section{Education Loan}

Children of the poor families fall into a severe problem at the time of paying their admission examination, and other fees. It is also found that some poor students cannot sit for the final examination as they fail to submit the required fees. ASA has come forward to save these students and introduced this program for the children of the group members. It is designed intending to help the group members in continuing their children's education. The highest loan size is Tk. 5,000 with $15 \%$ service charge and it is specially provided for meeting their admission and examination fees (Annual Report, 2010).

In 2010 Tk. 21 million was distributed among 6,269 members' children as education loan and on December 31, 2010, the outstanding amount of this program was Tk. 12 million. The recovery rate was $99.97 \%$ in this program (Annual Report, 2010).

\section{BRAC}

BRAC is one of the largest NGOs involved in primary education in Bangladesh. As of the end of 2012, it had more than 22,700 non-formal primary schools with a combined enrolment of 670,000 children (Wikipedia, July 2015).

BRAC's education program provides non-formal primary education to those left out of the formal education system, especially poor, rural, or disadvantaged children, and drop-outs. Its schools are typically one room with one teacher and no more than 33 students. Core subjects include mathematics, social studies, and English. The schools also offer extracurricular activities. Bangladesh has reduced the gap between male and female attendance in schools. The improvement in female enrolment, which has largely been at the primary level, is in part attributable to BRAC (Wikipedia, July 2015). BRAC has set up centers for adolescents called Kishori Kendra that provide reading material and serve as a gathering place for adolescents where they are educated about issues sensitive to the Bangladeshi society like reproductive health, early marriage, women's legal rights, etc. BRAC has also set up community libraries, 185 out of 964 of which are equipped with computers (Wikipedia, July 2015).

\section{Education}

BRAC's Non-Formal Primary Education program provides five-year primary education course in four years to poor, rural, disadvantaged children and dropouts that cannot access formal schooling. These oneroom schools are for children between eight and fourteen years of age. The schools also offer extracurricular 
activities. As of June 2008, 37,500 Primary Schools and 24,750 Pre-Primary schools have been established by BRAC enrolling nearly 3 million children, $65 \%$ of whom are girls. The schools have a drop-out rate of less than $5 \%$ (Annual Report, 2015).

\section{Scholarship}

Each year 50 under privilege students who achieved GPA 5 in SSC level get the scholarship. Among them, the students who repeat the GPA 5 in HSC level get scholarship for graduation. At present 514 students are availing scholarships (Annual Report, 2013).

\section{Grameen Bank}

Grameen Microcredit is helping to increase entitlement of microcredit program households on education through increasing capability to spend more on the education of children (Bhuiyan, B. A. Siwar, C, Ismail, G. A. and Hossain, B.T. 2013). In a climate of government disinterest in higher education equity in developing countries, one nongovernmental organization (NGO) in Bangladesh has unexpectedly begun its effort at financial aid in the higher education sector Grameen Kalyan, the welfare division of Grameen Bank, famous since 1983 for its innovative lending programs for the landless poor, has expanded its objectives beyond microenterprise to include higher education (Hopper, R. 1999).

The managing director of Grameen Kalyan, Shaikh Abdud Daiyan, states that NGOs must now begin to "consider the economy of the poor-and help them to rise to the highest levels of education." Grameen Kalyan has devised a program-the Higher Education Loan Program (Hopper, R. 1999).

\section{Scholarships}

Scholarships are given, every year, to the high performing children of Grameen borrowers, with priority on girl children, to encourage them to stay ahead to their classes. Up to May 2007, scholarships amounting to US $\$ 560,000$ have been awarded to 49,208 children. During 2007, US $\$ 775,000$ will be awarded to about 30,000 children, at various levels of school and college education (Yunus, M. 2005).

\section{Loan}

Students who succeed in reaching the tertiary level of education are given higher education loans, covering tuition, maintenance, and other school expenses. By May'07, 16,608 students received higher education loans, of them 15,531 students are studying at various universities; 191 are studying in medical schools, 347 are studying to become engineers, 539 are studying in other professional institutions (Yunus, M. 2005).

\section{DatA AND Methods}

Methodology plays an essential role to find out desire result. The appropriate methodology enables the researcher to collect valid and reliable information and to analyze the information properly to draw a clear-cut conclusion. This cross-sectional studying involving 200 male and female. Data is collected from both primary and secondary sources. Data are collected from different Upazilla and Zilla through questionnaire method during February to August 2015. Conducting the students whose, mothers are the member of Microcredit organization. The objective of this study is to find out the role of microcredit in the education of Bangladesh. Frequency distribution has been used on the data observation from 200 male and female, where they are students at different levels. This has been utilized to explore every level variables and the role of microcredit characteristics of the respondents and finally chi-square test binary logistic regression analysis have been used to estimate the existing relationships among the variables. The analysis of the data has been made using the statistical software SPSS-21 version.

\section{REsult AND Discussion}

The role of selected Micro-credit organization on the education of Bangladesh is disclosed. It is observed from the Table 1, most of the respondent $58.5 \%$ belongs to Sixteen to Twenty years age group, $1.5 \%$ belongs to Six to Ten, $15.5 \%$ belongs to Eleven to Fifteen years old, and $24.5 \%$ belongs to Twenty one and more age group. Micro-credit provides organization provides credit both for school, college and university going student. It should be noticed that from the selected student $23 \%$ are School level, $28 \%$ are college level, and $49 \%$ are university level student. From the selected student we noticed that $62.5 \%$ are male, and $37.5 \%$ are Female, who get credit from different microcredit organization. From the selected student we saw from the table $37.0 \%$ get credit from Grameen Bank, 37.5\% get from BRAC, $25.5 \%$ get credit from ASA. From the table we informed that $44.0 \%$ strongly agree, $34.5 \%$ agree, $5.0 \%$ neutral, $13.0 \%$ dis-agree and $3.5 \%$ strongly dis-agree that they have to repay the credit. Some time to get credit students have to pay interest on credit. $31.5 \%$ strongly agree, 53.5 agree, $7.0 \%$ are neutral, $6.5 \%$ are disagreed and $2.0 \%$ are strongly dis-agree that they have to pay interest when they repay the credit. Microcredit organization provides credit, but it may be or not sufficient student study. From the selected student we noticed that $7.5 \%$ are strongly agreed, $17.0 \%$ agreed, $8.5 \%$ neutral, 37.5 disagreed, and $19.5 \%$ are strongly disagreed that they get sufficient credit for study. Every micro credit organization gives credit that student who fulfills some condition. From the table 1 , we found that $40.5 \%$ are strongly agreed, $41.0 \%$ agree, $7.0 \%$ neutral, $9.0 \%$ disagree and $2.5 \%$ are strongly disagree that they have to fulfill some conditions to get the credit facilities. This selected organization also provides educational materials. 
The result of descriptive statistics have been demonstrated in table 1 where the frequency with percentage distribution of "Selected NGO's of Bangladesh.

\begin{tabular}{|c|c|c|}
\hline Characteristics & Frequency & Percentage \\
\hline Age & & \\
\hline Six to Ten & 3 & 1.5 \\
\hline Eleven to fifteen & 31 & 15.5 \\
\hline Sixteen to Twenty & 117 & 58.5 \\
\hline Twenty and More & 49 & 24.5 \\
\hline Education & & \\
\hline School & 46 & 23 \\
\hline College & 56 & 28 \\
\hline University & 98 & 98 \\
\hline Sex & & \\
\hline Male & 125 & 62.5 \\
\hline Female & 75 & 37.5 \\
\hline Organization & & \\
\hline Grameen Bank & 74 & 37 \\
\hline BRAC & 75 & 37.5 \\
\hline ASA & 51 & 25.5 \\
\hline Repay the credit & & \\
\hline Strongly agree & 88 & 44 \\
\hline Agree & 69 & 34.5 \\
\hline Neutral & 10 & 5 \\
\hline Disagree & 26 & 13 \\
\hline Strongly disagree & 7 & 3.5 \\
\hline Pay interest for credit & & \\
\hline Strongly agree & 62 & 31 \\
\hline Agree & 107 & 53.5 \\
\hline Neutral & 14 & 7 \\
\hline Disagree & 13 & 6.5 \\
\hline Strongly disagree & 4 & 2 \\
\hline Sufficient credit for study & & \\
\hline Strongly agree & 15 & 7.5 \\
\hline Agree & 34 & 17 \\
\hline Neutral & 37 & 18.5 \\
\hline Disagree & 75 & 37.5 \\
\hline Strongly disagree & 39 & 19.5 \\
\hline Possibility of drop out & & \\
\hline Strongly agree & 25 & 12.5 \\
\hline Agree & 70 & 35 \\
\hline Neutral & 73 & 36.5 \\
\hline Disagree & 22 & 11 \\
\hline Strongly disagree & 10 & 5 \\
\hline Should increase credit & & \\
\hline Strongly agree & 66 & 33 \\
\hline Agree & 96 & 48 \\
\hline Neutral & 13 & 6.5 \\
\hline Disagree & 17 & 8.5 \\
\hline Strongly disagree & 8 & 4 \\
\hline $\begin{array}{l}\text { Providing credit without } \\
\text { interest }\end{array}$ & & \\
\hline Strongly agree & 90 & 45 \\
\hline Agree & 63 & 3.5 \\
\hline Neutral & 19 & 9.5 \\
\hline Disagree & 18 & 9 \\
\hline Strongly disagree & 10 & 5 \\
\hline
\end{tabular}

\begin{tabular}{|l|l|l|}
\hline Satisfaction & 60 & 30 \\
Strongly agree & 95 & 47.5 \\
Agree & 17 & 8.5 \\
Neutral & 25 & 12.5 \\
Disagree & 3 & 1.5 \\
Strongly disagree & & \\
\hline Role of micro credit & 117 & 58.5 \\
Strongly agree & 49 & 24.5 \\
Agree & 12 & 6 \\
Neutral & 11 & 5.5 \\
Disagree & 10 & 5 \\
Strongly disagree & \multicolumn{2}{|l|}{} \\
\hline
\end{tabular}

From the interviewed student $8.5 \%$ are strongly agreed, $34.0 \%$ agree, $11.0 \%$ neutral, $21 \%$ disagree and $25.5 \%$ are strongly disagreed that these organizations give educational materials. Drop out is an important factor in education like Bangladesh. Some micro-credit organization has great role to reduce drop out. We noticed that $12.5 \%$ are strongly agreed, $35.0 \%$ agreed, $36.5 \%$ neutral, $11.0 \%$ disagreed, and $5.05 \%$ are strongly disagreed, that without getting these credit facilities they have the possibility to drop out. Cost of education is increasing day by day, so microcredit organization needs to increase the amount of credit. $33.0 \%$ are strongly agreed, $48.0 \%$ agreed, $6.5 \%$ neutral, $8.5 \%$ disagreed, and $4.0 \%$ are strongly disagreed, that microcredit providing organization should increase the amount of credit they give. It would be very helpful to the student if they get credit facilities without providing any interest when they repay it. From the table we noticed that among the students $45.0 \%$ are strongly agreed, 31.5\% agreed, $9.5 \%$ neutral, $9.0 \%$ disagreed, $5.0 \%$ are strongly disagreed, and that microcredit organizations should provide credit without interest. From the selected students 30.0\% are strongly agreed, $47.5 \%$ agreed, $8.5 \%$ neutral, $12.5 \%$ disagreed, and $1.5 \%$ are strongly disagreed, that they are satisfied to get such a credit facility. Role of Micro credit has a great role in the education Bangladesh. From the table we noticed that $58.5 \%$ are strongly agreed, $24.5 \%$ agreed, $6.0 \%$ neutral, $5.5 \%$ disagreed and $5.0 \%$ are strongly disagree that Microcredit providing organization has a great role in the education of Bangladesh. 
Table 2: Zero-order correlation of the role of microcredit in the education of Bangladesh and related characteristics

\begin{tabular}{|c|c|c|c|c|c|c|c|c|c|c|c|c|c|}
\hline & \begin{tabular}{|l|} 
Age \\
\end{tabular} & $\begin{array}{c}\text { Level } \\
\text { of } \\
\text { Edu } \\
\text { cation }\end{array}$ & Sex & $\begin{array}{l}\text { Organi } \\
\text { zation }\end{array}$ & $\begin{array}{l}\text { Repay } \\
\text { the } \\
\text { loan }\end{array}$ & \begin{tabular}{|c|} 
Pay \\
interest \\
For \\
loan \\
\end{tabular} & $\begin{array}{c}\text { Sufficient } \\
\text { credit }\end{array}$ & $\begin{array}{c}\text { Fulfill } \\
\text { ment of } \\
\text { condition }\end{array}$ & \begin{tabular}{|c|} 
Educa \\
tional \\
materials
\end{tabular} & $\begin{array}{c}\text { Possibility } \\
\text { of drop } \\
\text { out }\end{array}$ & $\begin{array}{c}\text { Increasing } \\
\text { credit }\end{array}$ & $\begin{array}{c}\text { Provide } \\
\text { credit } \\
\text { without } \\
\text { interest }\end{array}$ & $\begin{array}{c}\text { Satis } \\
\text { faction }\end{array}$ \\
\hline Age & 1 & $\begin{array}{c}.723 \\
(.000)\end{array}$ & $\begin{array}{l}.038 \\
(.591)\end{array}$ & $\begin{array}{l}.032 \\
(.653)\end{array}$ & $\begin{array}{c}.163 \\
(.021)\end{array}$ & $\begin{array}{c}.079 \\
(.269)\end{array}$ & $\begin{array}{c}.041 \\
(.562)\end{array}$ & $\begin{array}{l}-.058 \\
(.415)\end{array}$ & $\begin{array}{c}.225 \\
(.001)\end{array}$ & $\begin{array}{l}-.054 \\
(.448)\end{array}$ & $\begin{array}{l}-.137 \\
(.054)\end{array}$ & $\begin{array}{l}-.036 \\
(.610)\end{array}$ & $\begin{array}{c}-073 \\
(.303)\end{array}$ \\
\hline $\begin{array}{l}\text { Level of } \\
\text { education }\end{array}$ & & 1 & $\begin{array}{l}.006 \\
(.928) \\
\end{array}$ & $\begin{array}{l}.016 \\
(.826)\end{array}$ & $\begin{array}{l}.002 \\
(.982)\end{array}$ & $\begin{array}{l}-.044 \\
(.538)\end{array}$ & $\begin{array}{l}.134 \\
(.059)\end{array}$ & $\begin{array}{l}-.114 \\
(.109)\end{array}$ & $\begin{array}{l}.250 \\
(.000)\end{array}$ & $\begin{array}{l}-.097 \\
(.172)\end{array}$ & $\begin{array}{l}-.167 \\
(.018)\end{array}$ & $\begin{array}{l}-.126 \\
(.075)\end{array}$ & $\begin{array}{l}-.118 \\
(.097) \\
\end{array}$ \\
\hline Sex & & & 1 & $\begin{array}{c}.021 \\
(.763)\end{array}$ & $\begin{array}{l}-.019 \\
(.789)\end{array}$ & $\begin{array}{l}-.014 \\
(.841)\end{array}$ & $\begin{array}{c}.066 \\
(.353)\end{array}$ & $\begin{array}{l}-010 \\
(.888)\end{array}$ & $\begin{array}{l}-.028 \\
(.690)\end{array}$ & $\begin{array}{l}-.90 \\
(.205)\end{array}$ & $\begin{array}{l}-.019 \\
(.795)\end{array}$ & $\begin{array}{c}.052 \\
(.463)\end{array}$ & $\begin{array}{l}.021 \\
(.773)\end{array}$ \\
\hline Organization & & & & 1 & $\begin{array}{l}-.103 \\
(.146)\end{array}$ & $\begin{array}{c}.169 \\
(.017)\end{array}$ & $\begin{array}{c}.098 \\
(.169)\end{array}$ & $\begin{array}{c}.063 \\
(.373)\end{array}$ & $\begin{array}{l}-.132 \\
(.063)\end{array}$ & $\begin{array}{l}.115 \\
(.105)\end{array}$ & $\begin{array}{c}.059 \\
(.411)\end{array}$ & $\begin{array}{c}.024 \\
(.7330\end{array}$ & $\begin{array}{l}.075 \\
(.290)\end{array}$ \\
\hline $\begin{array}{l}\text { Repay the } \\
\text { loan }\end{array}$ & & & & & 1 & $\begin{array}{l}-.107 \\
(.132)\end{array}$ & $\begin{array}{l}-.145 \\
(.041)\end{array}$ & $\begin{array}{c}.104 \\
(.142)\end{array}$ & $\begin{array}{l}.153 \\
(.031)\end{array}$ & $\begin{array}{l}-.104 \\
(.144)\end{array}$ & $\begin{array}{l}-.116 \\
(.103)\end{array}$ & $\begin{array}{c}.044 \\
(.533)\end{array}$ & $\begin{array}{l}-.054 \\
(.444)\end{array}$ \\
\hline $\begin{array}{l}\text { Pay interest } \\
\text { for credit }\end{array}$ & & & & & & 1 & $\begin{array}{l}-.100 \\
(.160)\end{array}$ & $\begin{array}{c}.227 \\
(.001)\end{array}$ & $\begin{array}{l}-.077 \\
(.282)\end{array}$ & $\begin{array}{l}-.060 \\
(.398)\end{array}$ & $\begin{array}{c}.250 \\
(.000)\end{array}$ & $\begin{array}{c}.141 \\
(.046)\end{array}$ & $\begin{array}{l}.208 \\
(.003)\end{array}$ \\
\hline $\begin{array}{l}\text { Sufficient credit } \\
\text { for study }\end{array}$ & & & & & & & 1 & $\begin{array}{l}-.285 \\
(.000)\end{array}$ & $\begin{array}{c}.013 \\
(.853)\end{array}$ & $\begin{array}{c}.091 \\
(.202)\end{array}$ & $\begin{array}{l}-.317 \\
(.000)\end{array}$ & $\begin{array}{l}-.211 \\
(.003)\end{array}$ & $\begin{array}{l}-.287 \\
(.000)\end{array}$ \\
\hline $\begin{array}{l}\text { Fulfillment } \\
\text { of condition }\end{array}$ & & & & & & & & 1 & $\begin{array}{l}-.259 \\
(.000)\end{array}$ & $\begin{array}{l}-.006 \\
(.933)\end{array}$ & $\begin{array}{c}.146 \\
(.039)\end{array}$ & $\begin{array}{c}.287 \\
(.000)\end{array}$ & $\begin{array}{l}.321 \\
(.000)\end{array}$ \\
\hline $\begin{array}{l}\text { Educational } \\
\text { materials }\end{array}$ & & & & & & & & & 1 & $\begin{array}{l}.192 \\
(.006)\end{array}$ & $\begin{array}{l}-.077 \\
(.278)\end{array}$ & $\begin{array}{l}-195 \\
(.006)\end{array}$ & $\begin{array}{l}.028 \\
(.696)\end{array}$ \\
\hline $\begin{array}{l}\text { Possibility } \\
\text { of drop out }\end{array}$ & & & & & & & & & & 1 & $\begin{array}{c}.124 \\
(.081)\end{array}$ & $\begin{array}{c}.167 \\
(.018)\end{array}$ & $\begin{array}{l}.105 \\
(.139)\end{array}$ \\
\hline $\begin{array}{l}\text { Increasing } \\
\text { credit }\end{array}$ & & & & & & & & & & & 1 & $\begin{array}{l}.292 \\
(.000)\end{array}$ & $\begin{array}{c}.250 \\
(.000)\end{array}$ \\
\hline $\begin{array}{l}\text { Providing credit } \\
\text { without interest }\end{array}$ & & & & & & & & & & & & 1 & $\begin{array}{l}.245 \\
(.000)\end{array}$ \\
\hline Satisfaction & & & & & & & & & & & & & 1 \\
\hline
\end{tabular}

Note: The value of () indicates the p-value

Table 2 indicates that the results of zero-order correlation coefficients of the role of microcredit in the education of Bangladesh. From the Table 2, we found that age significantly positively correlated with level of education, organization, repay the loan, pay interest for credit, sufficient credit for study, educational materials, and negatively correlated with sex, fulfillment of conditions, possibility of drop out, should increase credit, providing credit without interest, satisfaction relatively their percentage are $(72.3 \%),(-3.8 \%),(3.2 \%),(16.3 \%),(7.9 \%)$, $(4.1 \%),(-5.8 \%),(22.5 \%),(-5.45),(-.13 .7 \%),(-.3 .6 \%),(-.7 .35)$. We found that level of education Positively correlated with sex, organization, repay the loan, sufficient credit for study, educational materials and their percentage are relatively $(.6 \%),(1.6 \%),(.2 \%),(13.4 \%),(25.0 \%)$. Level of education is also negatively correlated with pay interest for loan, fulfillment of conditions, possibility of drop out, shouldincrease credit, providing credit without interest, satisfaction and their percentage are relatively $(-11.4 \%)$, ($9.7 \%),(-16.7 \%),(-12.6 \%),(-11.8 \%)$. Sex positively correlated with organization sufficient credit for study, should provide credit without interest and their percentage are $(2.1 \%),(6.6 \%),(5.2 \%)$. Sex also negatively correlated with repay the loan, pay interest for loan, fulfillment of conditions, educational materials, possibility of drop out, should increase credit, satisfaction and their percentages are relatively $(-1.9 \%),(-1.4 \%),(-1.0 \%),(-2.8 \%),(-9.0 \%),(-1.9 \%),(-$ $2.1 \%)$. We observed that organization positively correlated with Paying interest for loan, sufficient credit for study, fulfillment of conditions, possibility of drop out, should increase credit, providing credit without interest, satisfaction and their percentage are relatively $(16.9 \%)$, $(9.8 \%),(6.3 \%),(11.5 \%),(5.9 \%),(2.4 \%),(7.5 \%)$. Organization negatively correlated with repay the loan, educational materials and their percentage are relatively $(-10.3 \%)$, ($13.2 \%$ ). Repay the loan positively correlated with the fulfillment of conditions, educational materials, providing credit without interest and their percentage are relatively $(10.4 \%),(15.3 \%),(4.4)$. Repay the loan also negatively correlated with pay interest for the loan, sufficient credit for study, the possibility of drop out, should increase credit, satisfaction, and their percentage are $(-10.7 \%),(-14.5 \%),(-$ $10.4 \%),(-11.6 \%),(-5.4 \%)$. Pay interest for credit positively correlated with the fulfillment of conditions, should increase credit, providing credit without interest, satisfaction and their percentages are relatively ( $22.7 \%$ ), $(25.0 \%),(14.1 \%),(20.8 \%)$. Pay interest for credit negatively correlated with sufficient credit for study, educational materials, the possibility of drop out and their percentages are relatively $(-10.0 \%),(-7.7 \%),(-6.0 \%)$. Sufficient credit for study positively correlated with educational materials, the possibility of drop out and their percentages are relatively $(1.3 \%),(9.1 \%)$. Sufficient credit for study also negatively correlated with the fulfillment of conditions, should increase credit, providing credit without interest, satisfaction and their percentages are relatively $(-28.5 \%)$, ($31.7 \%),(-21.1 \%),(-28.7 \%)$. We also noticed that fulfillment of conditions positively correlated with providing credit without interest, satisfaction and their percentages are relatively $(28.7 \%)$, (32.1\%). Fulfillment of conditions negatively correlated with educational materials, the possibility of drop out, should increase credit, and their 
percentages are relatively $(-25.9 \%),(-0.06 \%),(-14.65)$. It observed that educational materials positively correlated with satisfaction and the percentage is $(2.8 \%)$. Educational materials negatively correlated with the possibility of drop out, should increase credit, provide credit without interest and their percentages are relatively $(-19.2 \%),(-7.7 \%),(19.5 \%)$. From above, we found that possibility of drop out only positively correlated with should increase credit, providing credit without interest, satisfaction, and their percentages are relatively $(12.4 \%),(16.7 \%),(10.5 \%)$. Should increase credit positively correlated with providing credit without interest, Satisfaction, and their percentages are relatively $(29.2 \%)$, $(25.0 \%)$. Providing credit without interest positively correlated with satisfaction and percentage is $(24.5 \%)$.

\section{CONCLUSION}

Bangladesh is a poor, under developing and illiterate country. So most of the poor parents do not send their children to school because of poverty. If they were rich enough then they would send their child to school. So in this situation, Many Microcredit organizations come forward to help the poor parents to educate their children. They provide loans and also the scholarship. This is the study to find out the role of microcredit organization in the education of Bangladesh. From the above data and information, it can be said that microcredit are widely perceived as effective tools for educating the people are widely perceived as effective tools for educating the people of Bangladesh. Our findings from this study are that microcredit positively creates an impact on the education of Bangladesh. Microcredit helps Bangladesh to reduce the possibility to drop out. Sometime NGO's charge higher interest for the loan so it needs to decrease to support the education of Bangladesh. More educational materials should be providing. As Bangladesh is a poor country, the general tendency of the parents to engage his children in working. So, in this case NGO can play an important role to encourage the guardian and create awareness among the people about the importance of education. Besides providing loan, some microcredit organizations established many primary schools. They teach the student totally free, and all educational materials also provide without any fee. Our finding is from this study that microcredit has a positive role in education.

\section{REFERENCES}

Ahshanullah, M. Karim, R \&Haq, E. (2011). Reaching the Poor: Microcredit Experience in Bangladesh. ASA University Review, Vol. 5 No. 2, July-December, (2011).

Becchetti, L. Conzo P (2010). The Controversial Effects of Microfinance on Child Schooling: a Retrospective Approach. The University of Rome "Tor Vergata."

Bhuiyan, B. A. Siwar, C, Ismail, G. A. and Hossain, B.T. (2013). Microcredit Impact on Children's Education and Women Empowerment: A Review Experience of Grameen Bank Microfinance Schemes in Bangladesh. Research Journal of Applied Sciences, Engineering, and Technology 5(1): 66-71, 203, ISSN: 2040-7459; e-ISSN: 2040-7467.
BRAC (NGO) - Wikipedia, the free encyclopedia (2013). (Available at 13/02/2016). Retrieved from, https://en.wikipedia.org/wiki/BRAC_\%28NGO\%29\#Education

Feng, C.C. (2013) The Impact Of Microfinance On Household Expenditures For Health And Education. Washington DC. April 9, 2013.

Gibb, S. (2008) Microfinance's Impact on Education, Poverty, and Empowerment: A Case Study from the Bolivian Altiplano.Development Research Working Paper Series, No. 04/2008.

Holvoet, N. (2004). "Impact of Microfinance Programs on Children's Education - Do the Gender of the Borrowers and the Delivery Model Matter?" Institute of Development Policy and Management, University of Antwerp.

Holvoet, N. (2004) Impacts education sis os odelishatter? Journalised is

Hopper, R. (1999). World Bank, Washington D.C. Bangladesh: Grameen Bank's Higher Education Loan Program. International Higher Education.

Hytopoulos, E.

(2011). The impact of microfinance loans on children's educationalatta inment in rural thailand. University of California Press, Berkeley.

Kabir, M. A, Dey, S, and Islam, M. S. 2012. The Role of Micro credit and Micro Finance Institutions (MFIs) Extent and Intensity of poverty, poverty alleviation, and Outreach. International Affairs and Global Strategy, ISSN 2224-574X (Paper) ISSN 2224-8951 (Online) Vol 4, 2012.

Kumar, D. Hossain, A \& Chandra M. G. (2013) Role of Micro Credit Program in Empowering Rural Women in Bangladesh: A Study on Grameen Bank Bangladesh Limited. Asian Business Review, Volume 3, Number 4/2013.

Loro, L. (2013). Women's Empowerment as a Result of Microcredit Loans in Bangladesh? Bangladesh Development Research Working Paper Series (BDRWPS). BDRWPS 18 (September 2013).

Nai, E. (2010). The freedom to female empowerment: exploring the relationship between microcredit and education in bangladesh. Columbia undergraduate journal of south asian studies.

Yuge, Y. (2011). The Current Situation of Microfinance in Bangladesh:A Growing Concern about Overlapping Loan Problems - From a Field Visit to Rajshahi and Comilla. Student Research Series.

BRAC-annual-report-14.pdf. (Available at 13/02/2016). Retrieved from, http://www.brac.net/sites/default/files/ar2014/BRACannual-report-14.pdf

BRAC-annual-report-2013.pdf. (Available at 13/02/2016). Retrieved from, https://www.brac.net/sites/default/files/annualreport-2013/BRAC-annual-report-2013.pdf

ASA: Annual report, 2010 (Available at 18/3/2016). Retrieved from, http://asa.org.bd/wp-content/uploads/2015/04/annual_report_2010.pdf

ASA: Annual report, 2014-15. (Available at 18/03/2016). Retrieved from, http://asa.org.bd/wpcontent/uploads/2016/01/ASA-Annual-Report-2014-15-1.pdf.

Yunus, M. (2005). Grameen Bank At a Glance (available at 23/02/2016) Retrieved from http://www.grameeninfo.org/grameen-bank-at-a-glance /

$$
--0--
$$

